\title{
An investigation of the Cytotoxic, Cytogenetic and Teratogenic Potentials of Catharanthus roseus
}

\author{
Bushra Mohammed Amin Mohammed ${ }^{1}$, Sherzad Ibrahim Mustafa Amedi ${ }^{2}$ \\ 1Department of Biology, College of Science, University of Duhok, Duhok, Kurdistan Region, Northern Iraq. \\ ${ }^{2}$ Department of Pathology, College of Veterinary Medicine, University of Duhok, Duhok, Kurdistan Region, Northern Iraq
}

\begin{abstract}
This study was designed to evaluate the cytotoxic, genotoxic effects of the aqueous extract of Catharanthus roseus leaves on the somatic and germ cells of Swiss albino mice Mus musculus BALB/c strain, in addition to examine its teratogenic effect in pregnant mice on new infants. A preliminary step to evaluate the extract toxicity was to determine the lethal dose of the leaves aqueous extract; then three sub lethal doses were chosen $(0.767,0.383$, and $0.191 \mathrm{gm} / \mathrm{kg}$ of body weight) for the next experiments on the basis of the value of $L_{50}(7.67 \mathrm{gm} / \mathrm{kg})$ achieved in this study. The doses $0.767 \mathrm{gm} / \mathrm{kg}$ and $0.383 \mathrm{gm} / \mathrm{kg}$ exhibited significant mitotic arrest in a dose dependent manner, while extending treatment periods $(24,48$, and $72 \mathrm{hr}$.) did not show any significant increase in mitotic index percentage. The treatment of a single injections of the doses $(0.767,0.383$, and $0.191 \mathrm{gm} / \mathrm{kg})$ for three consecutive days induced significant but weak chromosome abnormalities represented almost by the centromeric chromosome fragments at the dose $0.767 \mathrm{gm} / \mathrm{kg}$, while chromosome breaks appears with a significant difference only when there was interaction between the dose $0.383 \mathrm{gm} / \mathrm{kg}$ and the period 24hours, the extending of treatment period (48 and $72 \mathrm{hr}$.) did not show any significant increase in the number of chromosome aberrations. Significant numbers of micronuclei were induced at the doses $0.767 \mathrm{gm} / \mathrm{kg}$ and $0.383 \mathrm{gm} / \mathrm{kg}$ after $24 \mathrm{hr}$. of administration. The results revealed that the plant extract showed a significant induction of sperm abnormalities at the three concentrations used comparing with the untreated animals. The administration of a single injection of $0.767 \mathrm{gm} / \mathrm{kg}$ of C. roseus extract to twenty pregnant females mice on the day 10 through 16 of gestation period did not show any apparent malformations. However, compared with the control population of the pup's number, body length, and head length was significantly reduced within the first day of life. Overall, those finding indicate that Catharanthus roseus aqueous extract can induce significant mitotic inhibition, slight chromosome aberrations and micronuclei frequencies and it can bring about significant percentage of abnormal spermatozoa, besides its ability to cross placental barrier causing some growth retardation; rather than teratogenic effects.
\end{abstract}

Keywords: Catharanthus roseus, Chromosome abnormalities, Toxicity, Micronuclei, Teratogenicity

\section{Introduction}

Catharanthus roseus (L.) G.Don, Apocynaceae, formerly called Vinca rosea (L.), is an ornamental, annual evergreen perennial shrub that occurs naturally in most warm regions of the world, including Iraq (1). It has been used in traditional medicine by various societies to treat various kinds of leukemia, skin cancer, lymph cancer, breast cancer, Hodgkin's disease (2), diabetes, hypertension, fever and hemostasis (3) .There are several other usages for this plant such as for the treatment of Malaria, a remedy for sore throat, for controlling bleeding, for treatment of dyspepsia, indigestion and dysmenorrheal (4).Catharanthus roseus has become one of the most interesting plants in the pharmaceutical industry, because it contains more than 120 terpenoid indole alkaloids (TIAs), and many of the alkaloids exhibit strong pharmacological activities (5). Previous studies have identified significant active compounds in $C$. roseus, including vinblastine and vincristine (anticancer), ajmalicine (antihypertensive) and serpentine (sedative) (5; 6 ). In spite of widespread use of this precious plant in different parts of the world, it had never been used in Kurdistan of Iraq folk remedy and to the best of our knowledge, there is no published data on the cytotoxicity, genotoxicity and teratogenicity of $C$. roseus leaves crude extract. Therefore the purpose of this study was to ensure the efficiency and safety of using the aqueous leaves extract of this herb to treat cancer, diabetes and other diseases, as did other countries, by testing its cytotoxicity, genotoxicity and teratogenicity properties in vivo.

\section{Materials and Methods}

A-Collection and extraction of Catharanthus roseus

Healthy, disease free, mature leaves of Catharanthus roseus pink variety was collected locally from Duhok University gardens. A voucher specimen of the plant was deposited to be identified and authenticated at the Agriculture and Forestry herbarium of Duhok University (Certificate number (4447) in (23/5/2014) A modified method of Roy \& Chatterjee (7) was used for the preparation of the aqueous extract of $C$ roseus; the dried leaves of the plant were ground to a fine powder using electric grinder and then the powder were suspended in distilled water for 12 hours, at the rate of $50 \mathrm{gm} / 200 \mathrm{ml}$; the obtained extract has been twice filtered through whattman No.42 filter paper and a clean brown filtrate was obtained. The filtrate was concentrated to semi dryness under reduced pressure and controlled temperature $\left(40-47{ }^{\circ} \mathrm{C}\right)$ using rotary evaporator. A deep brown colored residue was obtained, which was incubated in a clean Petri dish overnight at $\left(37^{\circ} \mathrm{C}\right)$ to obtain about $25 \%$ yield of extract. Finally the extract was kept in a dark closed container $\left(-4^{\circ} \mathrm{C}\right)$ and was used during 1-5 days.

\section{B-Animals and experimental design}

Cytogenetic and cytotoxic experiments were carried out on 8-10-week-old male Swiss albino mice (Mus musculus) $\mathrm{Balb} / \mathrm{c}$, weighing 25-30 g. They were maintained in a controlled atmosphere of $12 \mathrm{~h}$ dark/light cycle, $25 \pm 2^{\circ} \mathrm{C}$ temperature and had free access to food and water supply. The mice were divided into experimental groups of 5 animals. An extract of $C$ roseus leaves was administered in a 


\section{International Journal of Science and Research (IJSR) \\ ISSN (Online): 2319-7064 \\ Index Copernicus Value (2013): 6.14 | Impact Factor (2015): 6.391}

single dose of $1 \mathrm{ml}$ subcutaneously, at concentrations of $0.767,0.383$, and $0.191 \mathrm{gm} / \mathrm{kg}$ b.w. /day. The negative control group received $1 \mathrm{ml}$ phosphate buffer saline (PBS) The positive control group received subcutaneously injection of Gemcitabine at $15 \mathrm{mg} / \mathrm{kg}$ for bone marrow cells experiments and $10 \mathrm{mg} / \mathrm{kg}$ for sperm morphology assay. The Swiss albino mice were injected subcutaneously with $0.5 \mathrm{ml}$ of $10 \mathrm{mg} / \mathrm{kg}$ colchicine 2-3 hours, prior to sacrificing after each injection. The animals used in this study were sacrificed by cervical dislocation. All aspects of the animal experiment, breeding, parturitions were carried out in the Animal House of the Department of pathology, Faculty of veterinary medicine, University of Duhok.

\section{C-Cytotoxic assay:}

\section{1 - Determination of LD50:}

The LD50 was determined using the classical LD50 method according to Behrens and Karbers (8). Graded single doses of $C$ roseus $(4,6,8,10$, and 12) $\mathrm{gm} / \mathrm{kg}$ were administrated subcutaneously to five groups of mice, each of which consisted of six mice. Mortality was recorded after 24 hours.

\section{D-Cytogenetic assays}

1) Micronucleus (MN) assay:

Micronucleus (MN) assay, were prepared as recommended by Schimid (9). The slides were coded, fixed with methanol and stained with Giemsa solution. 500 polychromatic erythrocytes (PCE) from each animal were scored for micronucleus $(\mathrm{MN})$ presence.

2) Mitotic index (MI)assay:

The mitotic index (MI) was obtained by counting the number of mitotic cells in the 1, 000 cells analyzed per animal. MI \% analysis: The MI \%was determined as a ratio of the mitotic cells to the cells in metaphase in 1000 calculated cells.

M.I. \%=No. of dividing cells in metaphase $/\{$ Total No. of dividing cells + No. of non- dividing cells (1000) cells $\}$ X 100(10).

3) Chromosome aberrations assay:

Bone marrow preparations from the femur bones were used for the analysis of chromosome aberrations in metaphase cells, using the technique of Evans and Ford (11), for this test the extracts were administered daily for three consecutive days and the animals were sacrificed by cervical dislocation at 24,48 and 72 hours after the third medication.

4) Spermatozoa abnormalities assay:

For the analysis of spermatozoa abnormalities, the mice were sacrificed five weeks after the last day of sub-acute treatment (12). The spermatozoa were obtained by making small cuts in epididymis and vas deferens, placed in $1 \mathrm{ml}$ of normal saline .The sperm suspension obtained was stained with $0.05 \%$ of eosin-Y; smears were made on slides, air-dried and made permanent.

\section{E- Teratogenicity investigation}

To investigate the teratogenicity effect of $C$. roseus, adult female and male Swiss albino mice $(28-35 \mathrm{gm})$ of proven fertility were used for this experiment. Forty females at (1214) weeks of age were placed in the evening with mature males ( 2 female: 1 male). Copulation was checked by the presence of vaginal plug next morning or by the finding of sperm in the vaginal smear when vaginal plugs were less conspicuous than usual. When a plug was found or when spermatozoa were present, the females were separated and housed in groups for treatment. This time was called day zero of pregnancy. Twenty pregnant females were administered by a single subcutaneously injection at $0.767 \mathrm{gm} / \mathrm{kg}$ body weight of $C$ roseus aqueous extract on the day 10 through day 16 of gestation period. A further twenty pregnant mice were used as control group which received $1 \mathrm{ml}$ of PBS/day subcutaneously (13). All animals were observed daily throughout pregnancy, and then all dams were allowed to deliver naturally. At birth pups were examined carefully for external anomalies and they were examined for body weight, body length and head length (measured with a Vernier caliper) on postnatal day one.

\section{F-Statistical analysis}

The data obtained were submitted to the statistical program SAS (2005), Mitotic Index, Micronuclei, Sperm abnormalities, and pregnancy outcome in mice were analyzed using Completely Randomized Design (CRD) Chromosome Aberrations were analyzed using factorial $3 \times 5$ (CRD) to study the effect of treatments and $\mathrm{P}<0.05$ was considered statistically significant.

\section{Results and Discussion}

\section{A-Toxicity of $C$. roseus extract:}

Determination of the median lethal dose of a test substance is considered one of the very important steps to be done in experimental animals before any other experimental tests. This is to aid choosing the appropriate dose that can be employed in an experiment.

The experimental calculated $\mathrm{LD}_{\mathbf{5 0}}$ value in this study was $7.67 \mathrm{gm} / \mathrm{kg}$ of body weight as shown in table (1). To the best of our knowledge, a very few data on acute and sub chronic toxicity of $C$. roseus extract were available, despite the widespread use of the plant in various herbal remedies. Generally this herb is poisonous if ingested or smoked; it can cause poisoning in grazing animals (14)In this study, some behavioural changes were observed after 8-10 hours of subcutaneously administration of a single dose of 6-10 $\mathrm{gm} / \mathrm{kg}$, those changes included the loss of appetite, restlessness, diarrhea, impermanent blindness, loss in body weight, nervousness.. Some of those behavioural changes may reflect the peripheral neurotoxicity of $C$. roseus alkaloids (15).Sharma \& Ahmed (16) failed to reveal any mortality in mice following oral administration of the crude extract of $C$. roseus even at $10 \mathrm{gm} / \mathrm{kg}$ b.w. within 24 hours of administration. Also Chattopadhyay (17) studied the acute toxicity of graded doses of the ethanolic extract of $C$. roseus leaves in mice, no gross behavioural, neurologic and autonomic effects were observed after $24 \mathrm{hr}$. of orally administration and the $\mathrm{LD}_{50}$ value was found to be $3 \mathrm{gm} / \mathrm{kg}$ b.w. while Adekmoi (18) investigated the possible changes in structural and functional of liver and kidney in Wister rats following oral administration of the ethanolic leaves extract of $C$. roseus concluded that the extract have no toxic morphological on the kidney and liver at the doses 200, 300, $400 \mathrm{mg} / \mathrm{kg}$.

\section{Volume 5 Issue 6, June 2016 www.ijsr.net}




\section{International Journal of Science and Research (IJSR) \\ ISSN (Online): 2319-7064}

Index Copernicus Value (2013): 6.14 | Impact Factor (2015): 6.391

Table 1: The acute toxicity of $C$. roseus extract in male albino mice

\begin{tabular}{|c|c|c|c|}
\hline $\begin{array}{c}\text { Plant extract } \\
\text { doses }(\mathrm{gm} / \mathrm{kg})\end{array}$ & $\begin{array}{c}\text { Number of } \\
\text { Mice }\end{array}$ & $\begin{array}{c}\text { Number of } \\
\text { dead mice }\end{array}$ & $\begin{array}{c}\text { Precent of } \\
\text { mortality }\end{array}$ \\
\hline $\mathbf{1 2}$ & $\mathbf{6}$ & $\mathbf{6}$ & $\mathbf{1 0 0}$ \\
\hline $\mathbf{1 0}$ & $\mathbf{6}$ & $\mathbf{5}$ & $\mathbf{8 3 . 3 3 3}$ \\
\hline $\mathbf{8}$ & $\mathbf{6}$ & $\mathbf{3}$ & $\mathbf{5 0}$ \\
\hline $\mathbf{6}$ & $\mathbf{6}$ & $\mathbf{2}$ & $\mathbf{3 3 . 3 3 3}$ \\
\hline $\mathbf{4}$ & $\mathbf{6}$ & $\mathbf{0}$ & $\mathbf{0}$ \\
\hline
\end{tabular}

\section{B-Mitotic index (MI) assay}

The toxicity effects of different concentrations of $C$. roseus, periods, and their interaction on mitotic index are shown in table (2) the doses $0.767 \& 0.383 \mathrm{gm} / \mathrm{kg}$ shows significant inhibition $(\mathrm{p}<0.05)$ in mitotic index of mice bone marrow cells, Also the periods after injection, i.e. 24,48 , and $72 \mathrm{hr}$. did not show significant increase in mitotic index with the extending of treatment period.Another significant mitotic index value has been found in the interaction between doses and periods, but only at the first test concentration $(0.767$ $\mathrm{gm} / \mathrm{kg} \mathrm{b.w.)} \mathrm{for} \mathrm{the} \mathrm{periods} \mathrm{(48,} \mathrm{and} 72 \mathrm{hr}$.) with the values of $12.90 \pm 0.40$ and $11.60 \pm 1.088$ respectively. In fact $C$. roseus is a microtubule toxin; the mechanism involves binding its alkaloids to the tubulin monomers and preventing microtubule polymerization thus keeping the microtubules (spindle fibres) from forming and preventing cell division during the $\mathrm{M}$ phase of cell cycle (19).Moreover, C. roseus cytotoxicity was strongly correlated with both duration and concentration of drug treatment (20). At high concentration, its alkaloids cause microtubule depolymerisation, dissolve spindle microtubules and arrest cells in mitosis. While At low concentrations, they suppress microtubule dynamics, induce cell cycle arrest and apoptosis, but do not depolymerize microtubules (21). Similar results were obtained by El-Merzabani and colleagues (22) who explained that the leaves ethanol $(70 \%)$ extract when administered intraperitoneally to female mice exhibited significant MI inhibition.

Table 2: The Effect of various doses of Catharanthus roseus extract on mitotic index frequency in bone marrow cells of male albino mice

\begin{tabular}{|c|c|c|}
\hline \multicolumn{2}{|r|}{ factors } & $\begin{array}{c}\text { mitotic index } \\
(M I \%) \text { Mean } \pm S E\end{array}$ \\
\hline \multirow{5}{*}{$\tilde{\Xi}_{0}^{2}$} & PBS (N. Co.) & $14.90 \pm 0.081^{\mathrm{a}}$ \\
\hline & Gem.(P. Co.) $15 \mathrm{mg} / \mathrm{kg}$ & $8.20 \pm 0.075^{\mathrm{d}}$ \\
\hline & A.E. $0.767 \mathrm{gm} / \mathrm{kg}$ & $12.666 \pm 0.435^{\mathrm{c}}$ \\
\hline & A.E. $0.383 \mathrm{gm} / \mathrm{kg}$ & $13.766 \pm 0.465^{\mathrm{b}}$ \\
\hline & A.E. $0.191 \mathrm{gm} / \mathrm{kg}$ & $14.233 \pm 0.107^{\mathrm{ab}}$ \\
\hline \multirow{3}{*}{$\begin{array}{l}\tilde{z} \\
\bar{a} \\
\tilde{z}\end{array}$} & $24 \mathrm{hr}$. & $13.04 \pm 0.516^{\mathrm{a}}$ \\
\hline & $48 \mathrm{hr}$. & $12.80 \pm 0.53^{\mathrm{a}}$ \\
\hline & $72 \mathrm{hr}$. & $12.42 \pm 0.555^{\mathrm{a}}$ \\
\hline \multirow{11}{*}{ 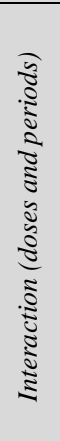 } & PBS (N. Co.) & $14.90 \pm 0.151^{\mathrm{a}}$ \\
\hline & Gem.(P. Co.) $15 \mathrm{mg} / \mathrm{kg}$ & $8.20 \pm 0.141^{\mathrm{d}}$ \\
\hline & A.E. $0.767 \mathrm{gm} / \mathrm{kg}(24 \mathrm{hr}$.) & $13.50 \pm 0.418^{\mathrm{ab}}$ \\
\hline & A.E. $0.767 \mathrm{gm} / \mathrm{kg}$ (48hr.) & $12.90 \pm 0.40^{\mathrm{bc}}$ \\
\hline & A.E. $0.767 \mathrm{gm} / \mathrm{kg}(72 \mathrm{hr})$. & $11.60 \pm 1.088^{\mathrm{c}}$ \\
\hline & A.E. $0.383 \mathrm{gm} / \mathrm{kg}(24 \mathrm{hr}$.) & $14.10 \pm 0.40^{\mathrm{ab}}$ \\
\hline & A.E. $0.383 \mathrm{gm} / \mathrm{kg}(48 \mathrm{hr})$. & $13.70 \pm 1.031^{\mathrm{ab}}$ \\
\hline & A.E. $0.383 \mathrm{gm} / \mathrm{kg}(72 \mathrm{hr})$. & $13.50 \pm 1.00^{\mathrm{ab}}$ \\
\hline & A.E. $0.191 \mathrm{gm} / \mathrm{kg}(24 \mathrm{hr})$. & $14.50 \pm 0.158^{\mathrm{ab}}$ \\
\hline & A.E. $0.191 \mathrm{gm} / \mathrm{kg}(48 \mathrm{hr}$.) & $14.30 \pm 0.122^{\mathrm{ab}}$ \\
\hline & A.E. $0.191 \mathrm{gm} / \mathrm{kg}(72 \mathrm{hr})$. & $13.90 \pm 0.187^{\mathrm{ab}}$ \\
\hline
\end{tabular}

\section{C-Chromosome Aberrations (CAs) Assay:}

The effect of different concentration of $C$. roseus, periods and their interactions on chromosome aberrations have been shown in table (3). Numerous structural chromosome aberration types were recorded such as chromatid breaks, chromosome breaks, centromere breaks, ring chromosome, dicentric chromosome, acentric chromosome fragments, and pulverization in all treated groups but the only significant ( $p$ $<0.05$ ) type of aberrations was the centromeric break at the highest dose $(0.767 \mathrm{gm} / \mathrm{kg})$ with the value $1.466 \pm 0.273$ comparing with the negative control. The number of aberrations did not increase significantly with the extending of the treatments period $(24,48$, and $72 \mathrm{hr}$.) as shown in table (3). However, the interaction between doses and periods has been found significantly different only in

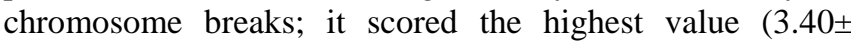
0.40 ), at the dose $0.383 \mathrm{gm} / \mathrm{kg}$ and the period $24 \mathrm{hr}$.

The information obtained from table (3) indicated weak Chromosome aberrations; only the centromeric chromosome fragments was induced by the chosen doses of the aqueous extract compared with the negative control group, figure (1) The cytogenetic changes in bone marrow cells observed with C. roseus aqueous extract might be due to the action of the plant alkaloids; these alkaloids have the ability to damage the spindle fibres and cause chromosome damage (23) However, several investigators proved that Vinblastine (24) and Vincristine (25) induce aneuploidy and chromosomal breakage in mouse bone marrow cells. The mechanism of Vinblastine action to cause chromosomal breakage is unknown, although several possible clastogenic mechanisms such interference with DNA synthesis, active metabolism and cytoplasmic endonucleases affects is yet to be elucidated $(24 ; 25)$.

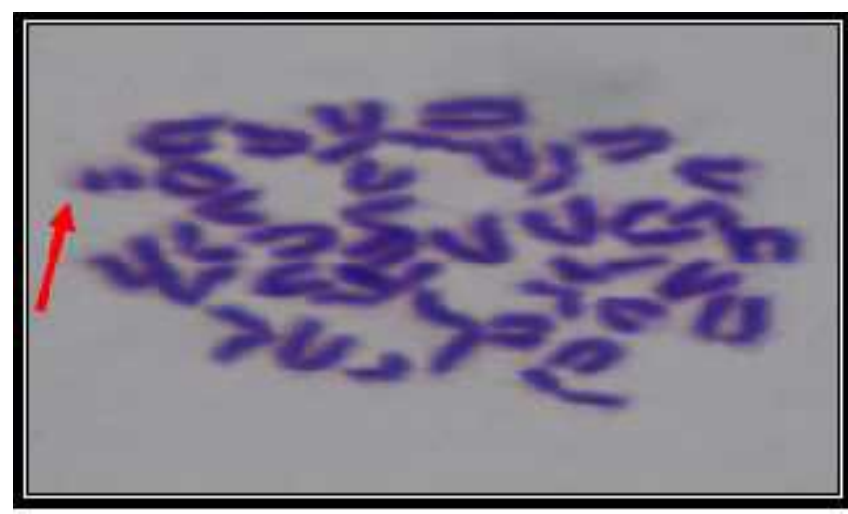

Figure 1: Centromeric break induced by C. roseus at the dose $0.767 \mathrm{gm} / \mathrm{kg}$.. 


\section{International Journal of Science and Research (IJSR) ISSN (Online): 2319-7064}

Index Copernicus Value (2013): 6.14 | Impact Factor (2015): 6.391

Table 3: Effect of C. roseus extract on Chromosome Aberrations in Male Albino Mice.

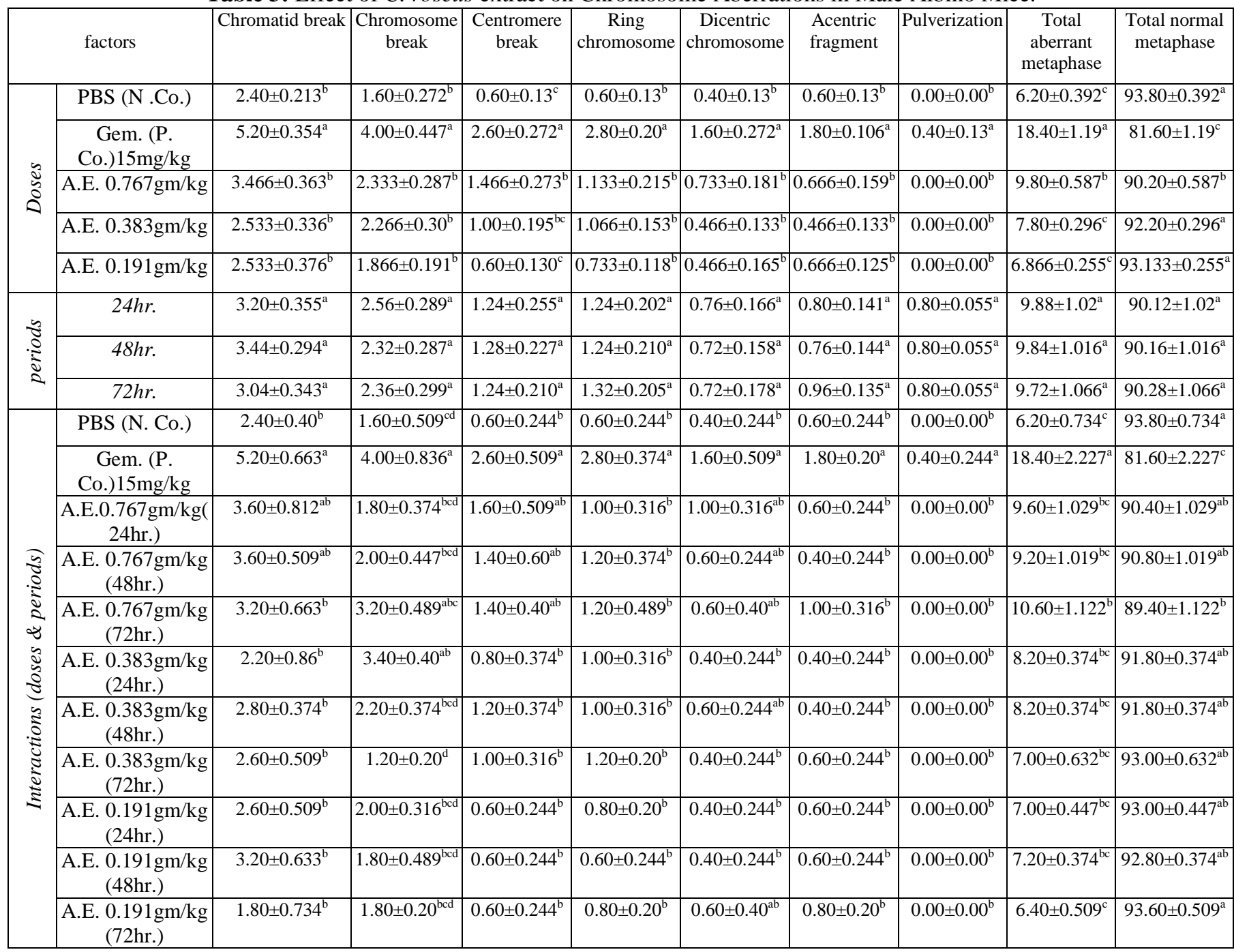

N. Co. : Negative control; Gem. : Gemcitabine; P. Co. : positive control; A.E. : Aqueous extract; hr.: hour. The different letters in the same column are significantly different at level $(p<0.05)$, All values given in the table are Mean \pm SE.

\section{D-Micronuclei Assay}

The result in table (4) and figure (2) reveals that the highest dose $0.767 \mathrm{gm} / \mathrm{kg}$ of the C. roseus extract caused the most significant induction of micronuclei in a dose dependent manner. It has been reported that spindle defects can directly generate double - strand DNA breaks (chromosome or chromatid break); those breaks localized in micronuclei and found adjacent to centromeres form the spindle attachment points in mitosis (26) So, in agreement with the result obtained in the current study and on the basis of the role of spindle, we suggest that chromosome breaks were generated in mitosis and segregation defects cause an increased frequency of lagging chromosomes leading to micronucleus occurrence in somatic cells of mice which may not reflect random chromosome break point positioning, but could result from small pieces of chromatin consisting of some centromeric materials. This may explain the significant centromeric chromosome fragment observed in this study. Similar reports are also available on the genotoxic effect of Vinblastine which was administered by single intraperitoneal doses $(0.5,1.0$, and $1.5 \mathrm{mg} / \mathrm{kg})$ to Swiss mice. It was found that Vinblastine increased numerous relatively large-sized $\mathrm{MN}$ after $30 \mathrm{hr}$. of treatment in a dose dependent manner (24). This study also agrees with other studies $(27 ; 23)$ which reveal that vincristine, Vinorelbine and Vinblastine induced a significant increase in micronuclei $(\mathrm{MN})$ frequencies in binucleated $(\mathrm{BN})$ cell, as well as producing slowing of the cell cycle, causing a decrease in the percentage of BN cells in cultured human lymphocytes and in female CD-1 mice.

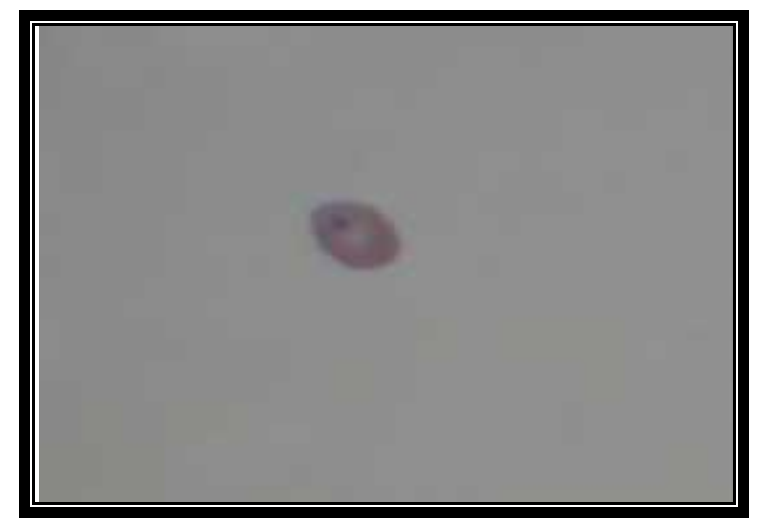

Figure 2: Single micronucleated cell induced by $C$. roseus at the dose $0.767 \mathrm{gm} / \mathrm{kg}$

\section{Volume 5 Issue 6, June 2016 www.ijsr.net}




\section{International Journal of Science and Research (IJSR) \\ ISSN (Online): 2319-7064}

Index Copernicus Value (2013): 6.14 | Impact Factor (2015): 6.391

Table 4: Effects of Catharanthus roseus extract on micronucleus frequency in bone marrow cells of male albino mice.

\begin{tabular}{|l|c|c|c|c|c|c|c|}
\hline Factors No. of MN & Single MN & Di MN & Tri MN & Tetra MN & Poly MN & $\begin{array}{c}\text { Total abnormal } \\
\text { micronucleated } \\
\text { cell }\end{array}$ & $\begin{array}{c}\text { Total normal } \\
\text { cell }\end{array}$ \\
\hline PBS (N. Co.) & $11.60 \pm 0.812^{\mathrm{b}}$ & $5.40 \pm 1.029^{\mathrm{ab}}$ & $0.40 \pm 0.244^{\mathrm{b}}$ & $0.00 \pm 0.00^{\mathrm{c}}$ & $0.00 \pm 0.00^{\mathrm{a}}$ & $17.40 \pm 1.691^{\mathrm{c}}$ & $482.60 \pm 1.691^{\mathrm{a}}$ \\
\hline Gem.(P. Co.) $5 \mathrm{mg} / \mathrm{kg}$ & $26.20 \pm 1.984^{\mathrm{a}}$ & $8.20 \pm 1.113^{\mathrm{a}}$ & $3.80 \pm 0.969^{\mathrm{a}}$ & $1.80 \pm 0.80^{\mathrm{ab}}$ & $0.80 \pm 0.374^{\mathrm{a}}$ & $40.80 \pm 3.916^{\mathrm{a}}$ & $459.20 \pm 3.916^{\mathrm{c}}$ \\
\hline A.E. $0.767 \mathrm{gm} / \mathrm{kg}$ & $14.40 \pm 1.630^{\mathrm{b}}$ & $6.80 \pm 0.80^{\mathrm{ab}}$ & $3.40 \pm 0.748^{\mathrm{a}}$ & $2.40 \pm 0.67 \mathrm{a}^{\mathrm{a}}$ & $0.80 \pm 0.374^{\mathrm{a}}$ & $27.80 \pm 2.634^{\mathrm{b}}$ & $472.20 \pm 2.634^{\mathrm{b}}$ \\
\hline A.E. $0.383 \mathrm{gm} / \mathrm{kg}$ & $13.40 \pm 1.208^{\mathrm{b}}$ & $3.80 \pm 0.969^{\mathrm{b}}$ & $2.80 \pm 0.583^{\mathrm{a}}$ & $0.80 \pm 0.20^{\mathrm{bc}}$ & $0.40 \pm 0.244^{\mathrm{a}}$ & $21.20 \pm 1.42 \mathrm{~b}^{\mathrm{bc}}$ & $478.80 \pm 1.428^{\mathrm{ab}}$ \\
\hline A.E. $0.191 \mathrm{gm} / \mathrm{kg}$ & $12.40 \pm 0.927^{\mathrm{b}}$ & $5.80 \pm 0.80^{\mathrm{ab}}$ & $0.80 \pm 0.489^{\mathrm{b}}$ & $0.20 \pm 0.20^{\mathrm{c}}$ & $0.00 \pm 0.00^{\mathrm{a}}$ & $19.20 \pm 1.655^{\mathrm{c}}$ & $480.80 \pm 1.655^{\mathrm{a}}$ \\
\hline
\end{tabular}

MN: micronuclei; N. Co.: Negative control; Gem. : Gemcitabine; P. Co.: positive control; A.E.: Aqueous extract. The different letters in the same column are significantly different at level $\left(p^{<} \mathbf{0 . 0 5}\right)$. All values given in the table are Mean $\pm \mathrm{SE}$.

\section{E-Abnormal Sperm Morphology Assay:}

The results of this work represent diversity in the type of abnormal sperms induced by different concentrations of $C$. roseus extract which are shown in table $(5 \mathrm{~A} \& \mathrm{~B})$ and figure (3). It is obvious from these data that there is a significant difference $(p<0.05)$ when compared with the negative control in the sperm head and tail shape; total number of abnormal sperms, sperms without head, amorphous head, banana head, defective hook, hook less, double tail defect, coiled tail defect, pseudo-droplet defect, corkscrew defect, sperm without tail, except the pin head, swollen head, and bent midpiece defect. Moreover, there was a significant difference between treatments on different sperm head abnormalities, the highest value of abnormal head sperms compared with the other mentioned shapes of head abnormalities were; in sperm without head at the dose $0.383 \mathrm{gm} / \mathrm{kg}$, amorphous head at the dose $0.767 \mathrm{gm} / \mathrm{kg}$, banana head and in defective hook at the dose $0,191 \mathrm{gm} / \mathrm{kg}$, hook less sperms at the dose $0.767 \mathrm{gm} / \mathrm{kg}$ as shown in table (5 A).A number of pervious researches confirmed the result observed in this work and reported that $C$. roseus extract and their metabolites can reach the testis and present in the semen, it has been reported that a regressive change in seminiferous tubules and leyding cells, increased cholesterol content in testis and degeneration of all germinal elements other than spermatogonia in male albino mice treated with aqueous extract of $C$. roseus for $24 \mathrm{hr}$ (28).

A single intraperitoneal exposure of vincristine at 24 hours, 4 weeks, and 8 weeks post treatment, show the induction of statistically significant percentages of aberrant spermatogonial metaphases, chromosome aberrations, and the occurrence of significant percentage of aberrant, primary spermatocytes with a typical bivalents and higher percentage of abnormal spermatozoa (sperm)in Swiss mice ( 29).Another study proved the cytotoxic and genotoxic effects of vincristine on germ cells of male mice, vincristine administration resulted in damage to DNA in spermatocytes and spermatids, reduction in the rate of germ cell development, and killing of the non-proliferating spermatid cells (30).

A through screening of literature revealed that the sperm morphological abnormalities may be due to a change in genetic material as the normal sperm head is very distinctive and any abnormalities might be influenced by genetic background $(31 ; 32)$.

However, the defect spindle of sperm nuclei which is expected in this study as a reflect of the exposure to $C$. roseus which could induce DNA double strand breaks as explained by Guerrero and his colleagues (26). Thus, it brings about DNA damage of germ cells which may cause the observed sperm head abnormalities (Table $5 \mathrm{~A}$ )

Table (5-A and B): The genotoxic effect of various doses of Catharanthus roseus extract on sperm morphology in male albino mice

Table (5-A) Sperm head abnormalities

\begin{tabular}{|c|c|c|c|c|c|c|c|c|c|c|c|}
\hline \multirow[t]{2}{*}{ Factor } & \multicolumn{11}{|c|}{ Head abnormalities sperm } \\
\hline & Pin head & $\begin{array}{c}\text { Swollen } \\
\text { head }\end{array}$ & $\begin{array}{l}\text { Without } \\
\text { head }\end{array}$ & $\begin{array}{c}\text { Amorphou } \\
\text { s head }\end{array}$ & $\begin{array}{c}\text { Ribbon } \\
\text { head }\end{array}$ & $\begin{array}{c}\text { Banana } \\
\text { head }\end{array}$ & $\begin{array}{c}\text { Double } \\
\text { hook }\end{array}$ & $\begin{array}{c}\text { Defective } \\
\text { hook }\end{array}$ & Hookless & $\begin{array}{c}\text { Long and } \\
\text { broad } \\
\text { hook }\end{array}$ & \begin{tabular}{|c|} 
Total \\
abnormal \\
head
\end{tabular} \\
\hline $\begin{array}{c}\text { PBS (N. } \\
\text { Co.) }\end{array}$ & $\begin{array}{c}3.80 \pm 0 . \\
800^{\mathrm{ab}}\end{array}$ & $\begin{array}{c}3.80 \pm 0.7 \\
34^{\mathrm{ab}}\end{array}$ & $\begin{array}{c}19.60 \pm 1.77 \\
7^{c}\end{array}$ & $\begin{array}{c}10.20 \pm 1.2 \\
40^{\mathrm{c}}\end{array}$ & $\begin{array}{c}4.20 \pm 1.42 \\
8^{\mathrm{ab}}\end{array}$ & $0.00 \pm 0.00$ & $\begin{array}{c}0.00 \pm 0.0 \\
0^{\mathrm{b}}\end{array}$ & $\begin{array}{c}1.20 \pm 0.58 \\
3^{\mathrm{c}}\end{array}$ & $\begin{array}{c}3.40 \pm 0.74 \\
8^{\mathrm{c}}\end{array}$ & $\begin{array}{c}0.80 \pm 0.58 \\
3^{\mathrm{b}}\end{array}$ & $\begin{array}{c}47.00 \pm 5.28 \\
7^{\mathrm{e}} \\
\end{array}$ \\
\hline $\begin{array}{c}\text { Gem. (P. } \\
\text { Co.) } \\
10 \mathrm{mg} / \mathrm{kg}\end{array}$ & $\begin{array}{c}4.40 \pm 1 \\
029^{\mathrm{a}}\end{array}$ & $\begin{array}{c}3.80 \pm 0.8 \\
60^{\mathrm{ab}}\end{array}$ & $\begin{array}{c}43.80 \pm 5.20 \\
0^{\mathrm{ab}}\end{array}$ & $\begin{array}{c}39.80 \pm 2.5 \\
17^{\mathrm{a}}\end{array}$ & $\begin{array}{c}7.40 \pm 0.97 \\
9^{\mathrm{a}}\end{array}$ & $\begin{array}{c}5.40 \pm 0.67 \\
8^{\mathrm{a}}\end{array}$ & $\begin{array}{c}0.40 \pm 0.2 \\
44^{\mathrm{a}}\end{array}$ & $\begin{array}{c}6.00 \pm 0.94 \\
8^{\mathrm{b}}\end{array}$ & $\begin{array}{c}6.60 \pm 0.67 \\
8^{\mathrm{b}}\end{array}$ & $\begin{array}{c}4.00 \pm 1.14 \\
0^{\mathrm{a}}\end{array}$ & $\begin{array}{c}121.60 \pm 5.3 \\
60^{\mathrm{a}}\end{array}$ \\
\hline $\begin{array}{c}\text { A.E. } \\
0.767 \mathrm{gm} / \mathrm{kg}\end{array}$ & $\begin{array}{c}1.40 \pm 0 . \\
400^{\mathrm{b}}\end{array}$ & $\begin{array}{c}3.40 \pm 0.8 \\
12^{\mathrm{ab}}\end{array}$ & $\begin{array}{c}38.20 \pm 2.51 \\
7^{\mathrm{b}}\end{array}$ & $\begin{array}{c}17.60 \pm 1.3 \\
63^{\mathrm{b}}\end{array}$ & $\begin{array}{c}5.40 \pm 1.63 \\
0^{\mathrm{ab}}\end{array}$ & $\begin{array}{c}2.80 \pm 0.66 \\
3^{\mathrm{bc}}\end{array}$ & $\begin{array}{c}0.00 \pm 0.0 \\
0^{\mathrm{b}}\end{array}$ & $\begin{array}{c}7.00 \pm 0.70 \\
7^{\mathrm{b}}\end{array}$ & $\begin{array}{c}10.80 \pm 0.8 \\
60^{\mathrm{a}}\end{array}$ & $\begin{array}{c}0.80 \pm 0.37 \\
4^{\mathrm{b}}\end{array}$ & $\begin{array}{c}87.40 \pm 2.22 \\
7^{c}\end{array}$ \\
\hline $\begin{array}{c}\text { A.E. } \\
0.383 \mathrm{gm} / \mathrm{kg}\end{array}$ & $\begin{array}{c}2.00 \pm 0 . \\
707^{\mathrm{ab}}\end{array}$ & $\begin{array}{c}1.40 \pm 0.5 \\
09^{\mathrm{b}}\end{array}$ & $\begin{array}{c}53.60 \pm 5.51 \\
9^{\mathrm{a}}\end{array}$ & $\begin{array}{c}16.40 \pm 1.4 \\
35^{\mathrm{b}}\end{array}$ & $\begin{array}{c}2.80 \pm 0.96 \\
9^{\mathrm{b}}\end{array}$ & $\begin{array}{c}0.80 \pm 0.20 \\
0^{\mathrm{cd}}\end{array}$ & $\begin{array}{c}0.00 \pm 0.0 \\
0^{\mathrm{b}}\end{array}$ & $\begin{array}{c}11.00 \pm 1.9 \\
49^{\mathrm{a}}\end{array}$ & $\begin{array}{c}10.20 \pm 1.7 \\
72^{\mathrm{a}}\end{array}$ & $\begin{array}{c}1.20 \pm 0.37 \\
4^{b}\end{array}$ & $\begin{array}{c}99.40 \pm 3.41 \\
4^{\mathrm{b}}\end{array}$ \\
\hline $\begin{array}{c}\text { A.E. } \\
0.191 \mathrm{gm} / \mathrm{kg}\end{array}$ & $\begin{array}{c}3.20 \pm 0 \\
860^{\mathrm{ab}}\end{array}$ & $\begin{array}{c}4.80 \pm 1.0 \\
67^{\mathrm{a}}\end{array}$ & $\begin{array}{c}22.60 \pm 1.74 \\
9^{c}\end{array}$ & $\begin{array}{c}6.60 \pm 1.02 \\
9^{c}\end{array}$ & $\begin{array}{c}6.40 \pm 0.92 \\
7^{\mathrm{ab}}\end{array}$ & $\begin{array}{c}4.60 \pm 1.16 \\
6^{\mathrm{ab}}\end{array}$ & $\begin{array}{c}0.00 \pm 0.0 \\
0^{\mathrm{b}}\end{array}$ & $\begin{array}{c}14.60 \pm 1.6 \\
30^{\mathrm{a}}\end{array}$ & $\begin{array}{c}9.60 \pm 0.81 \\
2^{\mathrm{ab}}\end{array}$ & $\begin{array}{c}1.60 \pm 0.50 \\
9^{b}\end{array}$ & $\begin{array}{c}74.00 \pm 2.48 \\
9^{\mathrm{d}}\end{array}$ \\
\hline
\end{tabular}




\section{International Journal of Science and Research (IJSR) \\ ISSN (Online): 2319-7064}

Index Copernicus Value (2013): 6.14 | Impact Factor (2015): 6.391

Table (5-B): Sperm Midpiece and tail aberrant types

\begin{tabular}{|c|c|c|c|c|c|c|c|c|c|}
\hline \multirow[b]{2}{*}{ Factor } & \multicolumn{6}{|c|}{ Tail abnormalities sperm } & \multirow{2}{*}{$\begin{array}{c}\text { Total abnormal } \\
\text { midpiece and } \\
\text { tail aberrant } \\
\text { types }\end{array}$} & \multirow{2}{*}{$\begin{array}{c}\text { Total abnormal } \\
\text { sperms }\end{array}$} & \multirow{2}{*}{$\begin{array}{c}\text { Total normal } \\
\text { sperms }\end{array}$} \\
\hline & $\begin{array}{c}\text { Double tail } \\
\text { defect }\end{array}$ & $\begin{array}{c}\text { Coiled tail } \\
\text { defect }\end{array}$ & $\begin{array}{l}\text { Pseud- } \\
\text { droblet } \\
\text { defect }\end{array}$ & $\begin{array}{c}\text { Corkscrew } \\
\text { defect }\end{array}$ & Without tail & $\begin{array}{c}\text { Bent midpiece } \\
\text { defect }\end{array}$ & & & \\
\hline $\begin{array}{c}\text { PBS (N. } \\
\mathrm{Co})\end{array}$ & $1.20 \pm 0.374^{\mathrm{a}}$ & $8.00 \pm 0.707^{d}$ & $6.80 \pm 0.374^{\mathrm{b}}$ & $24.20 \pm 3.720^{b}$ & $13.00 \pm 1.000^{d}$ & $12.80 \pm 0.860^{\mathrm{b}}$ & $66.00 \pm 4.301^{\mathrm{e}}$ & $113.00 \pm 8.789^{d}$ & $887.00 \pm 8.789^{\mathrm{a}}$ \\
\hline $\begin{array}{c}\text { Gem. (P. } \\
\text { Co) } 10 \mathrm{mg} / \mathrm{kg}\end{array}$ & $0.60 \pm 0.244^{\mathrm{ab}}$ & $76.80 \pm 4.017^{\mathrm{b}}$ & $4.40 \pm 1.077^{\mathrm{c}}$ & $57.40 \pm 5.124^{\mathrm{a}}$ & $33.60 \pm 2.712^{c}$ & $105.40 \pm 4.945^{a}$ & $278.20 \pm 8.834^{\mathrm{a}}$ & 399.8 & $1.600^{\mathrm{C}}$ \\
\hline $\begin{array}{c}\text { A.E. } \\
0.767 \mathrm{gm} / \mathrm{kg}\end{array}$ & $0.20 \pm 0.200^{\mathrm{b}}$ & $114.00 \pm 2.949^{2}$ & $1.20 \pm 0.583^{\mathrm{d}}$ & $11.20 \pm 0.860^{\mathrm{c}}$ & $80.00 \pm 5.567^{b}$ & $12.40 \pm 1.122^{\mathrm{b}}$ & $219.00 \pm 7.042^{\mathrm{b}}$ & $306.40 \pm 8.207^{\mathrm{b}}$ & $693.60 \pm 8.207^{\mathrm{c}}$ \\
\hline \begin{tabular}{c|} 
A.E. \\
$0.383 \mathrm{gm} / \mathrm{kg}$
\end{tabular} & $0.40 \pm 0.244^{b}$ & $77.60 \pm 1.989^{b}$ & $2.60 \pm 0.748^{\mathrm{cc}}$ & $20.80 \pm 1.714^{b}$ & $30.40 \pm 2.293^{c}$ & $17.00 \pm 2.469^{\mathrm{b}}$ & $148.80 \pm 1.655^{\mathrm{d}}$ & $248.20 \pm 3.382^{\mathrm{c}}$ & $751.80 \pm 3.382^{b}$ \\
\hline $\begin{array}{c}\text { A.E. } \\
0.191 \mathrm{gm} / \mathrm{kg}\end{array}$ & $0.00 \pm 0.00^{b}$ & $49.60 \pm 1.288^{\mathrm{c}}$ & $12.20 \pm 1.019$ & $1.60 \pm 0.400^{d}$ & $97.60 \pm 1.720^{2}$ & $14.40 \pm 1.503^{\mathrm{b}}$ & $175.40 \pm 3.722^{\mathrm{c}}$ & $249.40 \pm 5.095^{\mathrm{c}}$ & $750.60 \pm 5.095^{\mathrm{b}}$ \\
\hline
\end{tabular}
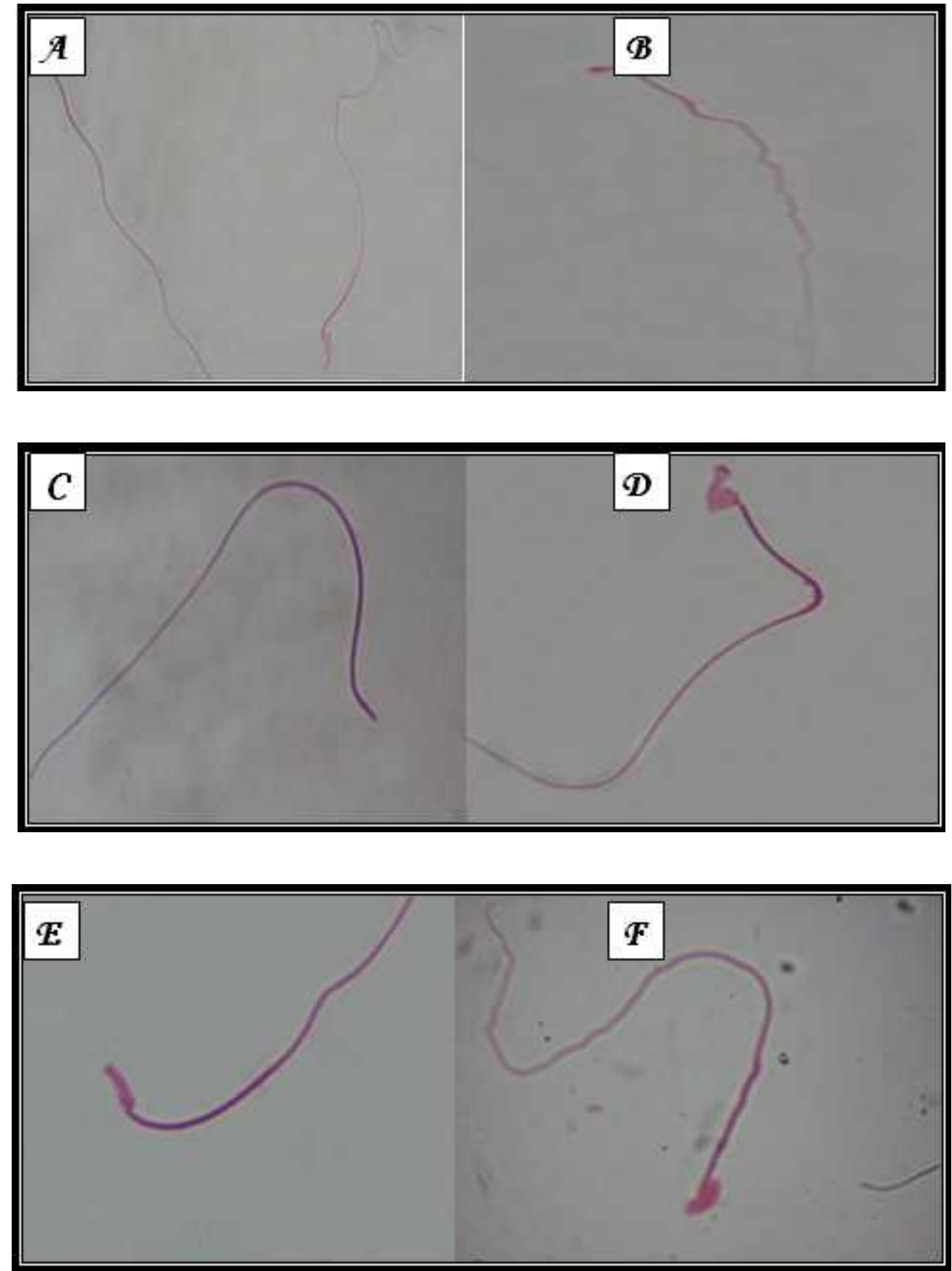

Figure 3: Some types of misshapen sperm induced by C. roseus in male albino mice (A: Normal sperm ; B : pin head ; C without head ; D : Amorphous head ; E Banana head: F : Hook less)

\section{Volume 5 Issue 6, June 2016} www.ijsr.net 


\section{International Journal of Science and Research (IJSR) \\ ISSN (Online): 2319-7064 \\ Index Copernicus Value (2013): 6.14 | Impact Factor (2015): 6.391}

\section{F-Teratogenicity evaluation}

The number of animals delivered, average of offspring number, average of body weight, average body length and average of head length on postnatal day one are shown in table (6); only the average of offspring number, body length and pups head length were reduced significantly from corresponding control, as shown in figure (3). No signs of deformities were observed in the treated mice. These results indicated absence of external teratogenic activity of the aqueous extract. The reduction of pup's number, body length, and head length may be due to the effect of $C$. roseus alkaloids such as vincristine, which could be strongly associated with the decreased mass of the ovary and uterus by its metabolization, therapeutic, toxicological or immunosuppressive action (33). Furthermore, vincristine could easily cross the placental barrier (33) which means it is a trans placental genotoxicants in mice. So $C$. roseus alkaloids might transmit its action to the next generation as it affects both female and male germ cells, but Vinblastine in mice did not necessarily lead to teratogenic effects (34). Moreover, no congenital malformations were noticed in 14 infants born to mothers treated with only vincristine (35). In fact, the action of $C$. roseus alkaloids on causing cytotoxicity, genotoxicity, and teratogenicity are strongly correlated with both duration and concentration of the extract treatment. On the basis of the results obtained in the present study, causing genotoxicity in both somatic and germ cells of Balb/c albino mice by $C$. roseus aqueous extract may produce cellular changes which might play an important role in initiating growth defects (developmental alterations). However, further intensive long term studies are required to reveal these adverse effects.

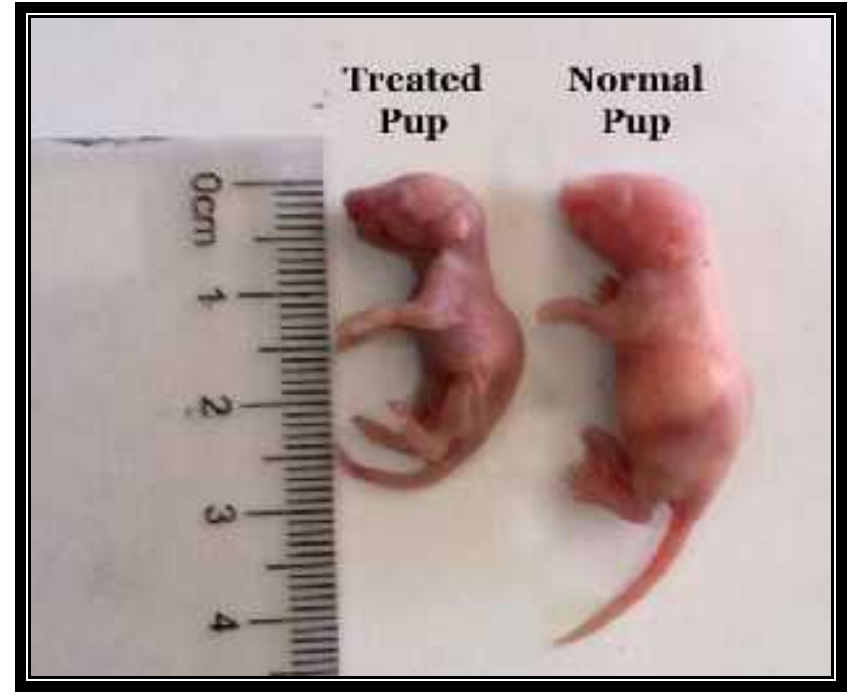

Figure 3: Show The reduction of pup's, body length, on postnatal day one, the pups were treated prenatally by a single subcutaneously injection at $0.767 \mathrm{gm} / \mathrm{kg}$ body weight of $C$ roseus extract on the day 10 through day 16 of gestation period.

Table 6: Effect of Catharanthus roseus extract on pregnancy and its outcome in mice

\begin{tabular}{|c|c|c|c|c|c|c|c|c|}
\hline Groups & $\begin{array}{c}\text { Number } \\
\text { of } \\
\text { females } \\
\text { mated }\end{array}$ & $\begin{array}{c}\text { Number } \\
\text { of } \\
\text { females } \\
\text { pregnant }\end{array}$ & $\begin{array}{c}\text { Number of } \\
\text { females } \\
\text { delivered }\end{array}$ & $\begin{array}{c}\text { Number of pups } \\
\text { howing external } \\
\text { deformities }\end{array}$ & $\begin{array}{c}\text { Average of } \\
\text { offspring } \\
\text { number }\end{array}$ & $\begin{array}{c}\text { Average pups } \\
\text { body weight (gm) } \\
\text { on day1 }\end{array}$ & $\begin{array}{c}\text { Average pups } \\
\text { body length (mm) } \\
\text { on day1 }\end{array}$ & $\begin{array}{c}\text { Average of pups } \\
\text { head length (mm) } \\
\text { on day1 }\end{array}$ \\
\hline PBS (N.co.) & 20 & 20 & 20 & 0 & $8.40 \pm 0.443^{\mathrm{a}}$ & $1.397 \pm 0.029^{\mathrm{a}}$ & $39.12 \pm 0.20^{\mathrm{a}}$ & $7.665 \pm 0.049^{\mathrm{a}}$ \\
\hline $\begin{array}{c}\text { C. roseus } \\
\text { A.E. }\end{array}$ & 20 & 20 & 19 & 0 & $6.75 \pm 0.354^{\mathrm{b}}$ & $1.336 \pm 0.032^{\mathrm{a}}$ & $35.832 \pm 0.452^{\mathrm{b}}$ & $6.885 \pm 0.146^{\mathrm{b}}$ \\
\hline
\end{tabular}

N. Co. : Negative control; A.E. : Aqueous extract. The different letters in the column are significantly different at level

( $p$ 0.05); the values given in the table are Mean \pm SE

\section{References}

[1] Lewis, Walter H, and Memory P.F. Elvin-Lewis. (2003). Medical Botany: Plants Affecting Human Health. Hoboken: John Wiley\& Sons.

[2] Christman, S. (2004). Catharanthus roseus. (Cited from: Http//www.2003 florida.com.) Date of download: 29/6/2011.

[3] Aslam, J.; Khan, S.H.; Siddiqui, Z.H.; Fatima, Z.; Maqsood, M. and Bhat, M.A. (2010). Catharanthus roseus (L.) G. Don. An important drug: its application and production. Pharmacie Global (IJCP).01(04):1-16.

[4] Mishra, M.P. Traditional -ethnoherbological and medicinal properties of Madagascar periwinkle. http://www.ecosensorium.org/2009/09/traditionalethnoh erbological-and.html

[5] Heijden, R.V.D.; Jacobs, D.; Snoeijer, W. and Verpoorte, R. (2004). The Catharanthus alkaloids: Pharmacognosy and biotechnology. Curr. Med. Chem. 11:607-628.
[6] Sottomayor, M. and Barceló, A.R. (2005). The Vinca alkaloids: from biosynthesis and accumulation in plant cells, to uptake, activity and metabolism in animal cells; In: Studies in Natural Products Chemistry (Bioactive Natural Products). Elsevier Science Publishers. The Netherlands: 813-857.

[7] Roy, S. and Chatterjee, P. (2010). A non-toxic antifungal compound from the leaves of Catharanthus roseus characterized as 5-hydroxy flavone by UV spectroscopic analysis and evaluation of its antifungal property by agar-cup method.Industrial crops and products 32: 375-380.

[8] Behrens, S. and Karbers, J. (1953). Determination of LD50. Arch. Fur. Exp.Path. Und. Pharm.:177-372.

[9] Schmid, W. (1975). The micronucleus test .Mutat. Res.31:9-15.

[10] Becker, W. (1986). The world of the cell. The Benjamin/Cammings Pub. Co. Inc. California.USA.

[11] Evans, E.P., Breckon, G. and Ford, C.F. 1964. An air drying method for meiotic preparation from mammalian testis. Cytogenetic, 3:289-294.

[12] Wyrobek, A.J. (1979). Changes in mammalian sperm morphology after $\mathrm{X}$ - ray and chemical exposure. Genetics. 59:105-119.

\section{Volume 5 Issue 6, June 2016 www.ijsr.net}




\section{International Journal of Science and Research (IJSR) \\ ISSN (Online): 2319-7064}

Index Copernicus Value (2013): 6.14 | Impact Factor (2015): 6.391

[13] Hejazi, S. (2009). Vincristine teratologic effect in newborn mice. In. J. Gynecology\& Obstetric. 107S2, S413- S729.

[14] Spiridon, K.E. and Maria, B. G. (2004). Plants that fight cancer. USA, CRC press LLC.

[15] Kufe, D. W.; Pollock, R. E.; Weichselbaum, R.R.; Bast, R.C., Gansler, T.S.; Holland, J.F. and Frei, E. (2003). Holland-Frei Cancer Medicine. 6th edition. Editors. Hamilton (ON): BC Decker.

[16] Sharma, J. and Ahmed, N. (1998). Preliminary studies on acute toxicity of Vinca rosea Linn in albino mice. Ind. J. of Indigenous and Medicine. 19(2):140-3.

[17] Chattopadhyay, R.R., (1999). A comparative evaluation of some blood glucose lowering agents of plant origin. J. Ethnopharmacol.67: 367-372.

[18] Adekmoi, D.A. (2010). Madagascar periwinkle (Catharanthus roseus) enhances kidney and liver functions in Wister rats. Int. J. of Biomedical and Health science. 6(4): 245-254.

[19] Sorosky, J.I.; Sood, A.K. and Buekers, T.E. (1997). the use of chemotherapeutic agents during pregnancy. Obstet Gynecol Clin North Am. 24(3):591-9.

[20] Howard, S.M.H.; Theologides, A. and Sheppard, J.R. (1980). Comparative effects of vindesine, vinblastine, and vincristine on mitotic arrest and hormone response of L1210 leukemia cells. Cancer Res. 40:2695.

[21]Zhou, J. and Giannakakou, P. (2005). Targeting microtubules for cancer chemotherapy. Current Medicinal Chemistry-Anticancer Agents.5 (1):65-71.

[22] El-Merzabani, M.M.; El-Aaser, A.A., and El-Duweini, A.K. (1979). A Bioassay of antimitotic alkaloids of Catharanthus roseus, Planta Med.36: 87-90.

[23] Xing, S. G.; Shi, X.; Wu, Z.L.; Chen, J.K.; Wallace, W.; Whong, W.Z. and Ong, T. (1992), Transplacental genotoxicity of triethylenemelamine, benzene, and vinblastine in mice. Teratogenesis, Carcinogenesis, and Mutagenesis. 12: 223-230.

[24] Satya-Praksh, K. L.; Liang, J. C.; Hsu, T. C. and Johnston, D. A. (1986). Chromosome aberrations in mouse bone marrow cells following treatment in vivo with vinblastine and colcemid. Environmental Mutagenesis.8: 273-282.

[25] Choudhury, R.C.; Palo, A.K. and Padhy, A. (2004). Cytogenetic Consequences of Vinblastine Treatment in Mouse Bone Marrow. Chemotherapy .50:171-177.

[26] Guerrero, A.A.; Gamero, M.C.; Trachana, V.; Fütterer, A.; Pacios-Bras, C.; Díaz-Concha, N.P.; Cigudosa, J.C.; Martínez-A, C. and Wely, K.H.V. (2010). Centromerelocalized breaks indicate the generation of DNA damage by the mitotic spindle. Proc Natl AcadSci $U S$ A. 107(9):4159-64.

[27] Gonzalez-cid, M.; Cuello, M. T. and Larripa, I.(1999). Comparison of the aneugenic effect of vinorelbine and vincristine in cultured human lymphocytes. Mutagenisis. 14(1):63-66.

[28] Murugavel, T.A.; Ruknudin, S.T. and Akbarsha, M.A. (1989). Antifertility effect of Vinca rosea (Linn.) leaf extract on male albino mice - a sperm parametric study. Curr Sci.58 (19): 1102- 1103.

[29] Choudhury, R.C.; Das, B.; Misra, S. and Jagdale, M.B. (2002). Spermatogonial cytogenetic toxicity of vincristine and its transmission in the germline cells of Swiss mice. J of Env. Path. Tox. Onco. 21(3):77.
[30]Zhang, Y. and Sun, K. (1992). Unscheduled DNA synthesis induced by the antitumor drug vincristine in germ cells of male mice. Mutation Research281(1):2529.

[31] Styrna, J.; Kilarski, W. and Krzanowska (2003) Influence of the CBA genetic background on the sperm morphology and fertilization efficiency in mice with a partial Y -chromosome deletion. Reproduction. 126:579-588.

[32] Chenoweth, P. J. (2005). Genetic sperm defects. Theriogenology. 64:457-68.

[33] Mattos, D.M.M.; Gomes, M.L.; Freitas, R.S. and Bernardo-Filho, M. (2001). Model to evaluate the toxic effect of drugs: vincristine effect in the mass of organs and in the distribution of radiopharmaceutical in mice. $J$ Mutation research. 496:137-143.

[34] Ungthavorn, S. and Joneja, M. (1969). Effects of teratogenic doses of vincristine on mitotic cells in the fetuses of DBA mice. American $J$ of Anatomy.126:291:297.

[35] Schardein, J. L. (1993). Chemically Induced Birth Defects, 2nd edn rev. Marcel Dekker, New York.

Volume 5 Issue 6, June 2016 www.ijsr.net 